Situs web: https://jurnal.uisu.ac.id/index.php/Bahastra
Vol. 4, No. 2, Maret 2020

Email: bahastra@fkip.uisu.ac.id

\title{
KONTRIBUSI MOTIVASI BELAJAR DAN PENGETAHUAN STRUKTUR BERITA TERHADAP KEMAMPUAN MENULIS BERITA SISWA KELAS VIII MADRASAH TSANAWIYAH KAMANG
}

\author{
Lisa Yuniarti \\ PBSI STKIP Adzkia Padang \\ lisayuniarti80@gmail.com
}

\begin{abstract}
Abstrak. Penelitian ini dilatarbelakangi oleh permasalahan yang terjadi pada siswa kelas VIII MTsN Kamang. Kemampuan menulis berita dipilih dalam penelitian ini disebabkan oleh rendahnya nilai rata-rata kemampuan menulis berita yang diperoleh siswa, yaitu 73 (berada dibawah KKM). Rendahnya nilai tersebut diduga berkaitan dengan motivasi belajar dan pengetahuan struktur berita yang dimiliki siswa. Penelitian ini bertujuan untuk mendeskripsikan seberapa besar kontribusi motivasi belajar dan pengetahuan struktur berita terhadap kemampuan menulis berita. Populasi penelitian ini adalah siswa kelas VIII MTsN Kamang yang berjumlah 120 orang. Metode penelitian yang digunakan adalah deskriptif analisis. Pengambilan sampel dalam penelitian ini dilakukan dengan menggunakan teknik simple random sampling yang menghasilkan sampel penelitian sebanyak 35 orang. Datapenelitian ini dikumpulkan dengan menggunakan instrumen berbentuk angket, tes objektif, dan tes unjuk kerja. Selanjutnya, data diolah dengan menggunakan rumus product moment, korelasi ganda, uji F, dan uji regresi ganda untuk mengetahui besarnya kontribusi antarvariabel yang diteliti.
\end{abstract}

Kata kunci: menulis teks berita, pembelajaran motivasi, pengetahuan struktur berita

\begin{abstract}
The background of this research is the problem that is happening in VIII year students if MTSN Kamang. The writer chooses the students ability in writing news because the students get low score, it is 73 (below the KKM). The writer predicts that there is a link between students motivation in studying and students' knowledge about news structure. The writer does this research ti describe how big the contribution of studying motivation and structure news in writing news.The population of this is the VIII year students of MTsN Kamang, consists of 120 students. The writer uses analysis desrciptive method. The technic that is used in this research is simple random sampling with 35 students in this research. The research is using some instruments such as questionnaire, optional test which is used to measure the news structure knowledge, and the writing test is used to measure the ability in writing news. Next, the data is processed using product moment
\end{abstract}


Kontribusi Motivasi Belajar dan Pengetahuan Struktur Berita terhadap Kemampuan Menulis

Berita Siswa Kelas VIII Madrasah Tsanawiyah Kamang

formula, double correlation, $F$ test, double regression test to know how

the contribution between the variable.

Key Mords: writing news texts, studying motivation, knowledge news structure

\section{PENDAHULUAN}

Menulis berita merupakan keterampilan yang menuntut proses berpikir sistematis dan logis karena adanya unsur-unsur $5 \mathrm{~W}+1 \mathrm{H}$ yang harus dikembangkan menjadi beberapa paragraf hingga menjadi sebuah berita. Unsurunsur tersebut menjawab pertanyaan apa, siapa, mengapa, di mana, kapan, dan bagaimana. Hal ini sesuai dengan pendapat Chaer (2010: 17-18) yang menjelaskan bahwa berita harus mengungkapkan unsur $5 \mathrm{~W}$ dan $1 \mathrm{H}$, yang mencakup what (apa yang terjadi), who (siapa yang terlibat dalam kejadian), why (mengapa kejadian itu terjadi), where (di mana kejadian itu terjadi), when (kapan terjadinya), dan how (bagaimana kejadiannya). Setiap berita harus mengandung keenam unsur tersebut dengan fakta-faktanya. Selain terdapat unsur-unsur berita, juga terdapat struktur berita. Struktur berita adalah bangunan atau susunan yang membentuk sebuah berita. Menurut Simbolon (1977:124), struktur berita terdiri dari judul berita (head line), baris tanggal (date line), teras berita atau paragraf awal (lead), dan paragraf-paragraf pelanjut (body). Bagian peristiwa yang dianggap paling penting, diletakkan dalam teras berita atau paragraf awal.

Berdasarkan hasil wawancara dengan siswa MTsN Kamang, diketahui siswa merasa tidak nyaman, cenderung bosan, dan kurang perhatian di kelas. Hal ini jika terus dilanjutkan akan berdampak pada rendahnya hasil belajar siswa. Oleh karena itu, untuk memdapatkan kegiatan pembelajaran yang optimal guru perlu menyesuaikan dengan materi yang akan diajarkan.

Berdasarkan hasil wawancara dengan guru yang mengajarkan bidang studi yang bersangkutan, pembelajaran bahasa Indonesia dalam hal ini pembelajaran menulis berita kurang mencapai hasil yang maksimal, baik dari segi motivasi maupun dari segi hasil proses pembelajaran yang diterapkan.

Berdasarkan hasil wawancara dengan siswa dan guru, hal tersebut disebabkan dua faktor, yakni faktor internal dan faktor eksternal. Faktor internal adalah faktor yang berasal dari dalam diri siswa, di antaranya: pemahaman, minat, bakat, motivasi dan pengetahuan, sedangkan faktor eksternalnya antara lain: wadah dan guru.

Faktor internal pertama adalah pemahaman siswa terhadap keterampilan menulis berita. Pemahaman siswa yang selalu beranggapan bahwa menulis berita itu adalah hal yang sulit menjadi faktor utama yang mempengaruhi keberhasilan dalam keterampilan menulis berita. Mereka beranggapan bahwa keterampilan menulis berita merupakan keterampilan yang rumit. Hal tersebut dikarenakan dalam kegiatan menulis berita, mereka dituntut untuk mampu menuangkan ide, ejaan, kalimat, kosakata dan tanda baca.

Faktor minat adalah adanya keinginan dari siswa untuk serius dalam mengikuti pelajaran menulis berita. Anggapan bahwa menuls berita 
Kontribusi Motivasi Belajar dan Pengetahuan Struktur Berita terhadap Kemampuan Menulis Berita Siswa Kelas VIII Madrasah Tsanawiyah Kamang

merupakan keterampilan yang rumit membuat sebagian siswa tidak berminat ketika pembelajaran mengenai menulis berita berlangsung. Selanjutnya faktor bakat, bakat adalah kompetensi awal yang telah dimiliki oleh siswa. Sebagaimana yang diketahui bahwa tidak semua siswa memiliki bakat yang sama. Sebagian siswa mungkin memiliki bakat di bidang olahraga, sains, dan ilmu sosial lainnya yang lebih menonjol.

Faktor selanjutnya adalah faktor motivasi. Sebenarnya, dalam pembelajaran apapun, motivasi menjadi sesuatu yang sangat berpengaruh. Sebagaimana hasil penelitian yang dilakukan oleh Harmaini pada tahun 2012, dalam penelitiannya yang berjudul "Pengaruh Persepsi Siswa tentang Profesionalitas Guru Mengajar dan Motivasi Belajar Terhadap Hasil Belajar Bahasa Indonesia pada SMK Se-Kota Bangkinang", yang menyimpulkan bahwa terdapat kontribusi yang signifikan antara motivasi belajar terhadap hasil belajar Bahasa Indonesia sebesar 22,94\%. Dalam keterampilan menulis berita, hasil penelitian tersebut mengindikasikan bahwa siswa yang memiliki motivasi belajar menulis berita yang tinggi, keterampilan menulis berita juga cenderung akan tinggi. Motivasi belajar juga dapat timbul karena adanya faktor intrinsik dan ekstrinsik. Seorang siswa akan memiliki motivasi belajar yang tinggi apabila di dalam dirinya terdapat hasrat dan keinginan untuk berhasil, dorongan kebutuhan belajar, serta adanya harapan akan cita-cita yang tinggi. Selain itu penghargaan lingkungan belajar yang kondusif dan kegiatan belajar yang

Jurnal Pendidikan Bahasa dan Sastra Indonesia menarik juga akan berpengaruh terhadap hasil belajar.

Faktor terakhir yang juga tidak kalah pentingnya adalah faktor pengetahuan. Menulis merupakan kegiatan yang kompleks, salah satunya menulis berita. Keterampilan ini tidak hanya menuntut siswa untuk mengetahui struktur berita, siswa juga dituntut untuk mampu memilih kata-kata dan kalimat yang tepat untuk mewakili ide, dan gagasan. Untuk mampu melakukan itu semua, seorang penulis harus memiliki penguasaan kosakata yang baik.

Berdasarkan pendapat di atas, untuk mampu menulis berita dengan baik, seseorang harus mampu memahami struktur berita secara cermat dan tepat. Sehingga kata-kata yang disusun sesuai dengan struktur berita mampu mewakili pikiran dan perasaan penulis. Orang yang mampu memilih kata-kata yang tepat dan cermat adalah orang yang memiliki kemampuan yang baik dalam penguasaan kosakata. Artinya jika ingin berhasil dalam menyampaikan ide, gagasan, pikiran, emosi dan perasaan dengan katakata yang tepat dan cermat dalam bentuk berita maka orang tersebut terlebih dahulu harus mempunyai pengetahuan yang baik mengenai kosakata. Teori di atas mengindikasikan bahwa pengetahuan struktur berita berpengaruh terhadap keterampilan menulis berita.

Selain faktor internal di atas, faktor eksternal juga memberikan pengaruh terhadap keterampilan menulis berita. Wadah merupakan tempat siswa menyalurkan bakatnya di bidang sastra khususnya menulis berita. Bagi siswa yang memiliki bakat dalam bidang ini, wadah merupakan faktor yang sangat 
Kontribusi Motivasi Belajar dan Pengetahuan Struktur Berita terhadap Kemampuan Menulis Berita Siswa Kelas VIII Madrasah Tsanawiyah Kamang

berperan dalam meningkatkan dan mengasah kemampuannya. Selanjutnya faktor guru, guru sebagai pihak yang paling berperan dalam menyampaikan ilmu pengetahuan, mempunyai andil yang sangat besar dalam mencapai tujuan pengajaran. Namun untuk mencapai tujuan yang diharapkan tersebut tidak hanya dibutuhkan kompetensi guru yang memadai, tetapi juga harus didukung dengan metode pengajaran yang sesuai. Untuk memenuhi kebutuhan tersebut, seorang guru dituntut untuk mampu menggunakan metode pengajaran yang praktis dan mudah untuk digunakan dalam kegiatan belajar mengajar di kelas maupun di luar kelas. Selain itu, guru juga harus mampu menciptakan suasana belajar yang nyaman.

Selanjutnya, hasil pengamatan sementara menunjukkan masih banyak siswa MTsN Kamang yang tidak dapat menulis berita secara baik dan benar sesuai dengan kompetensi dasar yang ditetapkan dalam Kurikulum Tingkat Satuan Pendidikan yaitu menulis teks berita secara singkat, padat dan jelas. Pembelajaran menulis berita siswa kelas VIII MTsN Kamang belum mencapai target KKM yaitu 73. Sebagai gambarannya adalah hasil tes awal/ulangan harian siswa yang pernah dilakukan sebelum melaksanakan penelitian. Hasil tes awal/ulangan harian siswa yang sudah dilaksanakan ternyata keterampilan menulis teks berita siswa kelas VIII MTsN Kamang belum mencapai ketuntasan minimal. Kenyataan ini menunjukkan bahwa keterampilan menulis teks berita siswa kelas VIII MTsN Kamang masih berkategori rendah dan perlu ditingkatkan.
Berdasarkan hasil penelitian yang dilakukan dan hasil wawancara, penulis berasumsi bahwa motivasi belajar dan penguasaan kosakata memiliki kontribusi terhadap keterampilan untuk menulis berita. Untuk memperkuat dugaan tersebut, penulis mencari teori yang mendukung. Teori yang penulis temukan untuk mendukung dugaan pertama, bahwa motivasi belajar berkontribusi terhadap keterampilan menulis berita adalah teori yang dikemukakan oleh Atkinson (dalam Djaali 2011: 106), yang menegaskan bahwa seseorang yang memiliki motivasi berprestasi yang tinggi pada umumnya harapan akan suksesnya selalu mengalahkan rasa takutnya akan kegagalan. Ia akan selalu merasa optimis dalam mengerjakan setiap apa yang dihadapinya dan selalu termotivasi untuk mencapai tujuan. Berdasarkan pendapat tersebut tergambar bahwa memang ada kaitan antara motivasi belajar dan hasil belajar. Keterampilan menulis berita merupakan hasil belajar yang diperoleh siswa setelah melaksanakan serangkaian proses belajar, jadi keterampilan menulis berita merupakan hasil belajar.

Berdasarkan pendapat di atas, jelas bahwa pengetahuan struktur berita memang berkontribusi terhadap keterampilan menulis berita. Seseorang yang mampu memilih kata-kata yang tepat dan mempertimbangkan perbedaan arti yang sekecil-kecilnya dari sebuah kata, adalah orang yang memiliki penguasaan kosakata dan struktur berita yang baik. Oleh karena itu, penulis merasa tertarik untuk mencari tahu seberapa besarkah konstribusi motivasi belajar dan penguasaan struktur berita terhadap keterampilan menulis berita. Hal 
Kontribusi Motivasi Belajar dan Pengetahuan Struktur Berita terhadap Kemampuan Menulis Berita Siswa Kelas VIII Madrasah Tsanawiyah Kamang

tersebutlah yang mendasari penulis untuk melakukan penelitian mengenai konstribusi motivasi belajar dan pengetahuan struktur beirta terhadap keterampilan menulis berita siswa kelas VIII MTsN Kamang.

METODE

Jenis penelitian dalam penelitian ini adalah penelitian kuantitatif. Penelitian kuantitatif merupakan penelitian yang menggunakan angka mulai dari pengumpulan data, penafsiran terhadap data, dan penampilan hasilnya (Arikunto, 2010:12). Metode yang digunakan dalam penelitian adalah metode deskriptif korelasional. Metode deskriptif tidak hanya memberikan gambaran terhadap fenomena-fenomena, tetapi juga menerangkan hubungan, menguatkan hipotesis, membuat prediksi serta mendapatkan makna dan implkasi dari suatu masalah yang ingin dicapai. Metode korelasional digunakan untuk mendeteksi besarnya suatu faktor yang berhubungan dengan variasi suatu faktor lain berdasarkan koefisien korelasinya.

Populasi dalam penelitian ini adalah siswa kelas VIII MTsN Kamang yang terdaftar pada tahun ajaran 2013/2014. Jumlah siswa yang terdaftar sebanyak 120 orang yang tersebar dalam 5 kelas, yakni: VIII.1 (24), VIII.2 (24), VIII.3 (24), VIII.4 (24), dan VIII.5 (25).

Penelitian ini dikumpulkan tiga jenis data, yaitu data motivasi belajar, pengetahuan struktur berita, dan kemampuan menulis berita. Masingmasing data memerlukan instrumen tersendiri. Data motivasi belajar dikumpulkan dengan menggunakan angket, data pengetahuan struktur berita dikumpulkan dengan menggunakan tes objektif, sedangkan data menulis berita dikumpulkan berupa hasil tes menulis berita.

\section{HASIL PENELITIAN}

\section{Kontribusi Motivasi Belajar terhadap Kemampuan Menulis Berita}

Hasil pengujian hipotesis pertama mengungkapkan, dengan menggunakan rumus koefisien determinasi, diperoleh koefisien determinasi $\mathrm{X}_{1}$ dengan $\mathrm{Y}$ sebesar 5,29\%. Angka tersebut menunjukkan bahwa $5,29 \%$ variabel kemampuan menulis berita (Y) ditentukan oleh variabel motivasi belajar $\left(\mathrm{X}_{1}\right)$. Dengan demikian, hipotesis pertama $\left(\mathrm{Ha}_{1}\right)$ yang berbunyi motivasi belajar siswa $\left(\mathrm{X}_{1}\right)$ berkontribusi terhadap kemampuan menulis berita (Y) dapat diterima.

Dari hasil penelitian diperoleh besarnya nilai koefisien korelasi motivasi belajar dengan kemampuan menulis berita sebesar 0,23 dan nilai $\mathrm{t}$ hitung sebesar 1,51. Berdasarkan analisis koefisien korelasi terdapat hubungan yang signifikan antara motivasi belajar dengan kemampuan menulis berita. Hal ini terbukti dari $\mathrm{t}$ hitung $(1,51)>\mathrm{t}$ tabel $(1,696)$. Selain itu, koefisien determinasi yang diperoleh sebesar 5,29\%, artinya variabel motivasi belajar memberikan kontribusi terhadap kemampuan menulis berita sebesar 5,29\%, sedangkan sisanya dipengaruhi oleh variabel lain. Jadi, dapat disimpulkan bahwa terdapat hubungan yang signifikan antara motivasi belajar dengan kemampuan menulis berita.

Berkaitan

dengan

motivasiSardiman

(2009:90)

mengungkapkan bahwa motivasi seseorang terhadap sesuatu dapat timbul pada salah satu dari dua kondisi, yaitu (1) 
Kontribusi Motivasi Belajar dan Pengetahuan Struktur Berita terhadap Kemampuan Menulis Berita Siswa Kelas VIII Madrasah Tsanawiyah Kamang

motivasi intrinsik muncul dari kesadaran diri sendiri tanpa pengaruh dari luar . artinya, motivasi intrinsik ini timbul dengan sendirinya tanpa ada paksaan atau dorongan dari luar untuk mencapai tujuan yang diharapkan, (2) motivasi ekstrinsik dapat juga dikatakan sebagai bentuk motivasi yang di dalamnya terdapat aktivitas belajar, hanya saja memerlukan dorongan dari luar untuk melakukan aktivitas. Dari uraian pendapat ahli, apabila dikaitkan dengan kondisi di sekolah, tampak bahwa peran sekolah sangat besar dalam upaya meningkatkan motivasi siswa untuk menjadikan kegiatan menulis sebagai kebutuhan bagi mereka.

Berdasarkan teori tersebut, dapat disimpulkan bahwa agar siswa terampil menulis berita, di samping latihan praktik siswa juga harus banyak membaca berbagai bacaan. Jika siswa memiliki motivasi belajar dan akan memiliki peluang untuk mendapatkan rujukan, bagaimana membuat sebuah berita menjadi sebuah berita yang baik. Motivasi belajar merupakan salah satu faktor yang memberikan kontribusi terhadap kemampuan menulis berita di samping berbagai faktor lainnya. Apabila motivasi belajar tinggi, makakemampuan menulis berita akan tinggi pula. Sebaliknya, apabila motivasi belajar rendah, maka kemampuan menulis berita akan rendah pula.

\section{Kontribusi Pengetahuan Struktur Berita terhadap Kemampuan Menulis Berita}

Hipotesis kedua $\left(\mathrm{H}_{2}\right)$ yang diajukan dalam penelitian ini adalah pengetahuan struktur berita $\left(\mathrm{X}_{2}\right)$ memiliki kontribusi terhadap kemampuan menulis berita (Y). Untuk memperoleh hasil deskripsi tentang kontribusi pengetahuan struktur berita $\left(\mathrm{X}_{2}\right)$ terhadap kemampuan menulis (Y) perlu ditentukan besarnya koefisien determinasi dari kedua variabel penelitian tersebut. Dengan menggunakan rumus koefisien determinasi itu, diperoleh koefisien determinasi $\mathrm{X}_{2}$ dengan $\mathrm{Y}$ sebesar $16 \%$. Angka tersebut menunjukkan bahwa $16 \%$ variabel kemampuan menulis berita (Y) ditentukan oleh variabel pengetahuan struktur berita $\left(\mathrm{X}_{2}\right)$. Dengan demikian, hipotesis pertama $\left(\mathrm{Ha}_{1}\right)$ yang berbunyi pengetahuan struktur berita $\left(\mathrm{X}_{2}\right)$ berkontribusi terhadap kemampuan menulis berita (Y) dapat diterima.

Dari hasil penelitian diperoleh
besarnya nilai koefisien korelasi pengetahuan struktur berita dengan kemampuan menulis berita sebesar 0,40 dan nilai $t$ hitung sebesar 2,52. Berdasarkan analisis koefisien korelasi terdapat hubungan yang signifikan antara pengetahuan struktur berita dengan kemampuan menulis berita. Hal ini terbukti dari $\mathrm{t}$ hitung $(2,52)>\mathrm{t}$ tabel $(1,696)$. Selain itu, koefisien determinasi yang diperoleh sebesar 16\%, artinya variabel pengetahuan struktur beritamemberikan kontribusi terhadap kemampuan menulis berita sebesar 16\%, sedangkan sisanya dipengaruhi oleh variabel lain. Jadi, dapat disimpulkan bahwa terdapat hubungan yang signifikan antara pengetahuan struktur beritadengan kemampuan menulis berita.

Berdasarkan data yang diperoleh dari indikator pengetahuan struktur berita terlihat banyak siswa yang memberi nilai tinggi. Terlihat bahwa semakin tinggi pengetahuan struktur berita yang dimiliki seorang siswa, semakin tinggi juga 
Kontribusi Motivasi Belajar dan Pengetahuan Struktur Berita terhadap Kemampuan Menulis Berita Siswa Kelas VIII Madrasah Tsanawiyah Kamang

kemampuan menulis berita siswa yang dimiliki oleh siswa tersebut. Sebaliknya, semakin rendah pengetahuan struktur berita seorang siswa, semakin rendah juga kemampuan menulis berita siswa tersebut. Jadi, jelas bahwa terdapat hubungan positif antara pengetahuan struktur berita dengan kemampuan menulis berita.

Sebuah berita yang utuh terdiri dari tiga bagian utama, yakni headline, lead dan The remainder of the story (Karthik, 2012). Headline adalah bagian judul yang paling menarik perhatian pembaca. Menurut Karthik, headline memang bertujuan untuk menangkap perhatian pembacanya sehingga pembaca rela berhenti hanya untuk membacanya. "It makes us stop and look. It tells us quickly what the story covers. Its primary function is to attract our attention."Headline juga dibuat untuk menceritakan sekilas mengenai isi berita yang akan disampaikan dan tujuan utamanya adalah untuk menarik perhatian pembaca.

Lead adalah paragraf pembuka pada sebuah berita. "Always this lead remains the primary concern of the newspaper writer. In any form of writing the writer tries to put his best food foremost." Lead adalah bagian utama yang terpenting pada sebuah berita, terutama berita pada media cetak. Pada bagian ini, penulis menuliskan bagian terbaik dari inti cerita yang ditulisnya, karena bagian ini adalah bagian terpenting. Begitu juga dengan Deahl (2012) yang menyatakan bahwa lead atau lede-istilah slang jurnalis adalah "an incredibly important part of the process" yakni bagian yang sangat penting dari proses penulisan berita.
Lead disusun atas rumusan pertanyaan $5 \mathrm{~W}+1 \mathrm{H}$ yakni "What" (apa), "Who" (siapa), "When" (kapan), "Where" (dimana), "Why" (mengapa) dan "How" (bagaimana).

Bagian yang ketiga, menurut Karthik adalah the remainder of the story atau bagian yang tersisa, atau yang sering kita ketahui sebagai body paragraph. Karthik berpendapat bahwa terdapat pola khusus penyusunan paragraf tubuh (body). Penulis memilih fakta atau insiden terpenting yang ada di paragraf lead, kemudian penulis mengembangkan fakta, insiden, ataupun detail-detail yang bersifat penting. Selanjutnya, diikuti oleh faktafakta penting yang mendukung. Kemudian diikuti fakta pendukung yang sifatnya kurang penting namun tetap harus dimasukkan dalam berita tersebut, hingga mengerucut ke ulasan yang paling tidak penting pada penutup.

Berdasarkan teori yang telah diuraikan tersebut, dapat disimpulkan bahwa pengetahuan struktur beirta merupakan salah satu faktor yang memberikan kontribusi terhadap kemampuan menulis berita di samping berbagai faktor lainnya. Apabila pengetahuan struktur berita tinggi, kemampuan menulis berita akan tinggi pula. Sebaliknya, apabila pengetahuan struktur berita rendah, maka kemampuan menulis berita akan rendah pula. Sebelum memulai pelajaran guru perlu memotivasi siswa dengan menjelaskan pentingnya belajar kepada siswa yang akan menuntun mereka untuk mendapatkan hal-hal yang akan membawa manfaat bagi mereka sekarang dan masa datang. Jadi, guru dituntut lebih aktif memotivasi siswa dengan memberikan bahan pembelajaran 
Kontribusi Motivasi Belajar dan Pengetahuan Struktur Berita terhadap Kemampuan Menulis Berita Siswa Kelas VIII Madrasah Tsanawiyah Kamang

yang menarik kepada siswa supaya siswa tetap termotivasi untuk belajar.

\section{Kontribusi Motivasi Belajar $\left(\mathbf{X}_{1}\right)$ dan Pengetahuan Struktur Berita $\left(\mathbf{X}_{2}\right)$ terhadap Kemampuan Menulis Berita (Y)}

Hipotesis ketiga $\left(\mathrm{H}_{3}\right)$ dalam penelitian ini adalah variabel motivasi belajar $\left(\mathrm{X}_{1}\right)$ dan pengetahuan struktur berita $\left(\mathrm{X}_{2}\right)$ secara bersama-sama berkontribusi terhadap variabel kemampuan menulis berita (Y). Pengujian hipotesis ketiga dilakukan dengan uji korelasi ganda. Sebelum uji korelasi ganda perlu dilakukan uji korelasi PPM. Hal itu dimaksudkan untuk mengetahui besarnya koefisien korelasi variabel motivasi belajar $\left(\mathrm{X}_{1}\right)$ dengan pengetahuan struktur berita $\left(\mathrm{X}_{2}\right)$.Sesuai dengan tujuan penelitian yang terdapat pada bab I, yaitu memperoleh hasil deskripsi tentang kontribusi motivasi belajar dan pengetahuan struktur berita terhadap kemampuan menulis berita. Agar tujuan penelitian tersebut tercapai, selanjutnya perlu ditentukan koefisien determinasi atau koefisien penentu dari korelasi variabel motivasi belajar $\left(\mathrm{X}_{1}\right)$ dan pengetahuan struktur berita $\left(\mathrm{X}_{2}\right)$ dengan kemampuan menulis berita (Y). Berdasarkan penghitungan yang diperoleh dari rumus koefisien determinasi variabel motivasi belajar $\left(\mathrm{X}_{1}\right)$ dan pengetahuan struktur berita $\left(\mathrm{X}_{2}\right)$ berkontribusi secara bersama-sama terhadap kemampuan menulis berita (Y). Hal tersebut berarti bahwa 21,16\% kemampuan menulis berita (Y) ditentukan oleh motivasi belajar $\left(\mathrm{X}_{1}\right)$ dan pengetahuan struktur berita $\left(\mathrm{X}_{2}\right)$. Dengan demikian, dapat disimpulkan bahwa hipotesis ketiga $\left(\mathrm{Ha}_{3}\right)$ yaitu motivasi belajar $\left(\mathrm{X}_{1}\right)$ dan pengetahuan struktur berita $\left(\mathrm{X}_{2}\right)$ berkontribusi secara bersama-sama terhadap kemampuan menulis berita $(\mathrm{Y})$. Jadi, hipotesis $\left(\mathrm{Ha}_{3}\right)$ dalam penelitian ini dapat diterima.

Dari hasil penelitian diperoleh besarnya nilai koefisien korelasi motivasi belajar dan kemampuan menulis berita dengan kemampuan menulis berita0,46 dan nilai $t$ hitung sebesar 6,29. Berdasarkan analisis koefisien korelasi terdapat hubungan yang signifikan antara motivasi belajar dan pengetahuan struktur berita dengan kemampuan menulis berita. Hal ini terbukti dari t hitung $(6,29)>t$ tabel (1,696). Selain itu, koefisien determinasi yang diperoleh sebesar $21,16 \%$ artinya variabel motivasi belajar danpengetahuan struktur beritamemberikan kontribusi terhadap kemampuan menulis berita sebesar $21,16 \%$, sedangkan sisanya dipengaruhi oleh variabel lain. Jadi, dapat disimpulkan bahwa terdapat hubungan yang signifikan antara motivasi belajar dan pengetahuan struktur berita dengan kemampuan menulis berita.

\section{PEMBAHASAN}

Pada perolehan persentase motivasi belajar dan pengetahuan struktur berita 5,29\% dan 16\%, tampak angka tersebut sebuah persentase yang cukup besar. Peneliti berpendapat demikian karena pada dasarnya banyak faktor lain yang juga menentukan kemampuan menulis berita yang diperoleh siswa. Hasil analisis yang diperoleh juga memberikan gambaran bahwa ternyata motivasi belajar lebih kecil jika dibandingkan dengan pengetahuan struktur berita, sedangkan pengetahuan struktur berita relatif memberikan sumbangan jauh lebih besar dibandingkan dengan motivasi belajar. 
Kontribusi Motivasi Belajar dan Pengetahuan Struktur Berita terhadap Kemampuan Menulis Berita Siswa Kelas VIII Madrasah Tsanawiyah Kamang

Selain itu, temuan ini juga menegaskan bahwa motivasi belajar dan pengetahuan struktur berita memang memberikan sumbangan terhadap kemampuan menulis berita, namun banyak faktor lain yang juga menentukan kemampuan menulis berita siswa.

Seseorang yang memiliki motivasi belajar akan lebih banyak tulisan atau karya dan bacaan yang pernah dibuatnya dan dibacanya daripada yang kurang memiliki motivasi belajar. Dengan banyaknya tulisan yang pernah dibuat akan menambah pengetahuan yang dimiliki oleh siswa. Ini akan sangat berpengaruh terhadap kemampuan menulis berita. Menulis membutuhkan perbendaharaan kata yang banyak, sehingga memudahkan mereka dalam menulis. Soedarso (2005:58) mengatakan bahwa kemampuan tiap dalam memahami apa yang dibaca berbeda-beda, salah satunya tergantung pada perbendaharaan kata, minat, jangkauan mata, kecepatan interpretasi dan tujuan membaca tersebut. Dengan adanya saling keterkaitan antara motivasi belajar, pengetahuan struktur berita dan menulis berita, guru berperan cukup besar dalam peningkatan ketiga variabel ini. Sebagai contoh, dalam memotivasi siswa untuk belajar guru dapat memberikan teknik-teknik yang bervariasi dalam pembelajaran Bahasa Indonesia.

Sesuai dengan pendapat Slamet (2008:71) secara umum keterampilan menulis siswa dipengaruhi oleh dua faktor, yaitu faktor kebahasaan dan faktor nonkebahasaan. Faktor kebahasaan meliputi penggunaan kaidah bahasa tulis, penguasaan kosakata, penggunaan kalimat efektif, penguasaan semantik, penguasaan paragraf, dan wacana. Faktor nonkebahasaan meliputi sikap, minat, motivasi, kebiasaan belajar, usia, tingkat pendidikan, kurikulum, guru, dan lingkungan. Berdasarkan pendapat tersebut dapat disimpulkan bahwa motivasi belajar dan pengetahuan struktur berita merupakan salah satu faktor yang berperan dalam menentukan kemampuan menulis berita. Oleh karena itu, semakin tinggi motivasi belajar dan pengetahuan struktur berita siswa, maka akan semakin tinggi pula kemampuan menulis berita.

\section{SIMPULAN}

Berdasarkan analisis data dan pembahasan yang telah dikemukakan pada bab IV dapat disimpulkan bahwa terdapat kontribusi motivasi belajar dan pengetahuan struktur berita terhadap kemampuan menulis berita siswa kelas VIII MTsN Kamang. Pertama, kontribusi motivasi belajarterhadap kemampuan menulis berita adalah sebesar 5,29\%. Maksud dari data tersebut adalah motivasi belajar memberikan kontribusi sebesar $5,29 \%$ terhadap kemampuan menulis berita, sedangkan sisanya 94,71\% dipengaruhi oleh faktor lain. Persentase rata-rata motivasi belajar siswa diperolehsebesar 57,01\%. Maksudnya, kemampuan rata-rata motivasi belajar berada pada cukup. Dari uraian tersebut, terlihat bahwa motivasi belajar pada penelitian ini harus lebih ditingkatkan lagi karena semakin tinggi motivasi belajar, maka semakin tinggi juga kemampuan menulis berita. Sebaliknya, semakin rendah motivasi belajar, maka semakin rendah kemampuan menulis berita. Kedua, kontribusi pengetahuan struktur berita terhadap kemampuan menulis berita sebesar $16 \%$. Artinya adalah pengetahuan struktur berita memberikan kontribusi 
Kontribusi Motivasi Belajar dan Pengetahuan Struktur Berita terhadap Kemampuan Menulis Berita Siswa Kelas VIII Madrasah Tsanawiyah Kamang

terhadap kemampuan menulis berita sebesar $16 \%$, sedangkan sisanya sebesar $84 \%$ ditentukan oleh faktor lain. Untuk persentase rata-rata siswa terhadap kemampuan menulis berita adalah sebesar 65,05\%. Artinya, rata-rata motivasibelajarsiswadalampenelitianiniber adalebih dari cukup. Berdasarkan data tersebut, dapat disimpulkan bahwa pengetahuan struktur berita merupakan salah satu faktor yang memberikan kontribusi terhadap kemampuan menulis berita di samping berbagai faktor lainnya. Berdasarkan hasil yang diperoleh pengetahuan struktur berita siswa harus ditingkatkan dengan menumbuhkan pengetahuan struktur berita tersebut pada pribadi siswa dengan salah satu cara yaitu guru harus mampu memberikan dorongan agar bisa menumbuhkan semangat belajar siswa. Apabila pengetahuan struktur berita tinggi, maka kemampuan menulis berita akan tinggi pula. Sebaliknya, apabila pengetahuan struktur berita rendah, maka kemampuan menulis berita akan rendah pula.

Ketiga, kontribusi motivasi belajar dan pengetahuan struktur berita terhadap kemampuan menulis berita sebesar 21,16\%. Artinya, motivasi belajar dan pengetahuan struktur berita secara bersama-sama sebesar $21,16 \%$, sedangkan sisanya sebesar 78,84\% dipengaruhi oleh variabel lain. Siswa yang memiliki motivasi belajar dan pengetahuan struktur berita yang baik dipastikan dapat meningkatkan kemampuan menulis berita siswa tersebut, walaupun masih banyak variabel lain yang mempengaruhi kemampuan menulis berita. Untuk persentase rata-rata siswa terhadap variabel kemampuan menulis berita sebesar 72,11\%. Artinya, kemampuan rata-rata kemampuan menulis berita siswa dalam penelitian ini berada pada kualifikasi cukup. Jadi, dapat disimpulkan bahwa terdapat hubungan yang signifikan antara motivasi belajar dan pengetahuan struktur berita dengan kemampuan menulis berita.

\section{SARAN}

Bertolak dari hasil penelitian, maka disarankan hal-hal sebagai berikut. Pertama, siswa hendaknya meningkatkan kegiatannya dalam hal berlatih menulis. Hal itu dilakukan agar mereka memperoleh banyak ilmu dan pengetahuan. Kedua, guru diharapkan dapat meningkatkan profesionalnya sebagai pendidik. Selain itu, meskipun guru hanya menjadi fasilitator tetapi guru juga harus memberikan pemahaman konsep kepada siswa, sehingga mereka memiliki pegangan yang jelas dalam praktik. Artikel ini ditulis dari tesis penulis pada Program Pascasarjana Universitas Negeri Padang dengan tim pembimbing, yaitu Prof. Dr. Harris Effendi Thahar., M.Pd., dan Dr. Ngusman, M.Hum.

\section{DAFTAR PUSTAKA}

Arikunto, Suharsimi. 2010. Manajemen Penelitian. Jakarta: Rineka Cipta.

Chaer, Abdul. 2010. Bahasa Jurnalistik. Jakarta: Rineka Cipta.

Deahl, Rachel. 2012. News Writing: The Essentials of News Writing, (http://mediacareers.about.com/o d/thenecessaryskills/a/WritingSk ills.htm) diakses pada 24 November 2013.

Deahl, Rachel. 2012. What is Hard News?, (http://mediacareers.about.com/o 
Kontribusi Motivasi Belajar dan Pengetahuan Struktur Berita terhadap Kemampuan Menulis Berita Siswa Kelas VIII Madrasah Tsanawiyah Kamang

d/glossary/g/HardNews.htm)

diakses pada 25 November

2013.

Djaali. 2009. Psikologi Pendidikan. Jakarta: Bumi Aksara

Karthik, Praveen. 2012. What are the Three Main Parts of a News Story, (http://www.preservearticles.co $\underline{\mathrm{m} / \text { what-are-the-three-main- }}$ parts-of-a-news-story.html) diakses pada 25 November 2012.

Sardiman. 2011. Interaksi dan Motivasi Belajar Mengajar. Jakarta: rajawali press.

Simbolon, Parakitri T. 1997. Vademekum Wartawan: Reportase Dasar. Jakarta: Kepustakaan Populer Gramedia.

Slameto. 1995. Belajar dan Faktor-faktor yang Mempengaruhinya. Jakarta: Rineka Cipta. 